\title{
ROLE OF ETIOLOGICAL FACTOR IN PATHOLOGICAL EVENTS OF METABOLIC DISORDERS
}

\author{
Dr Nisha Tripathi' ${ }^{1}$ Vd. Ragini Patil2, Vd. Rajesh Mhaske², Vd Satyendra Singh4, Vd Suresh Shinde ${ }^{5}$ \\ 'M.D. Sch., Rog Nidan Evum Vikriti Vigyan, College of Ayurveda and Research Center, Nigdi, Pune, India. \\ 2Principal, HOD, Rog Nidan Evam Vikruti Vidnyan, College of Ayurved \& Research Center, Nigdi, Pune, India. \\ 3Professor, Rog Nidan Evam Vikruti Vidnyan, College of Ayurved \& Research Center, Nigdi, Pune, India. \\ ${ }^{4}$ Reader, Rog Nidan Evam Vikruti Vidnyan, College of Ayurved \& Research Center, Nigdi, Pune, India. \\ 5Lecturer, Rog Nidan Evam Vikruti Vidnyan, College of Ayurved \& Research Center, Nigdi, Pune, India.
}

\begin{abstract}
The current health status of global population severely facing problems related to the metabolic disorders and such types of health issues seeking attention of medical physician since incidences increases day by day. Ayurveda explained term Santarpanjanya Vikaras on the basis of symptomatic similarities with defective tissue metabolism. Improper dietary habits, indulgence in sedentary life style, genetic and environmental factors may disturb Agni leading to the production of Ama and vitiation of Rasa \& Medadhatu accompanying Dosha aggravation can triggers pathogenesis of metabolic disorders. Sthaulya and Prameha, etc. can be considered as metabolic disorders. diseases which affects health status of society badly. Ayurveda described Santarpanjanya Vikaras as diseases due to the defective metabolism. It is believed that Rasa, Meda, Rakta, Mamsa, Srotasa, Dosha and Agni mainly get hampered in metabolic disorders. Considering high number of prevalence of such cases this article emphasizes role of etiological factors associated with metabolic disorders.
\end{abstract}

Key-Words: Ayurveda, Metabolic Disorders, Etiological Factors, Sthaulya, Prameha. 
Introduction

Medoroga \& Prameha are considered as major metabolic disorders which affects most of the common population of higher age group. Many etiological factors causes diseases pathogenesis including Pichhila, Guru and Snigdha Ahara Sevana, Madyapana, Avyayama, Diwaswapa, Chinta and Atiasan behavior, etc. The major metabolic disorders as per Ayurveda depicted in Figure $\mathbf{1}$.

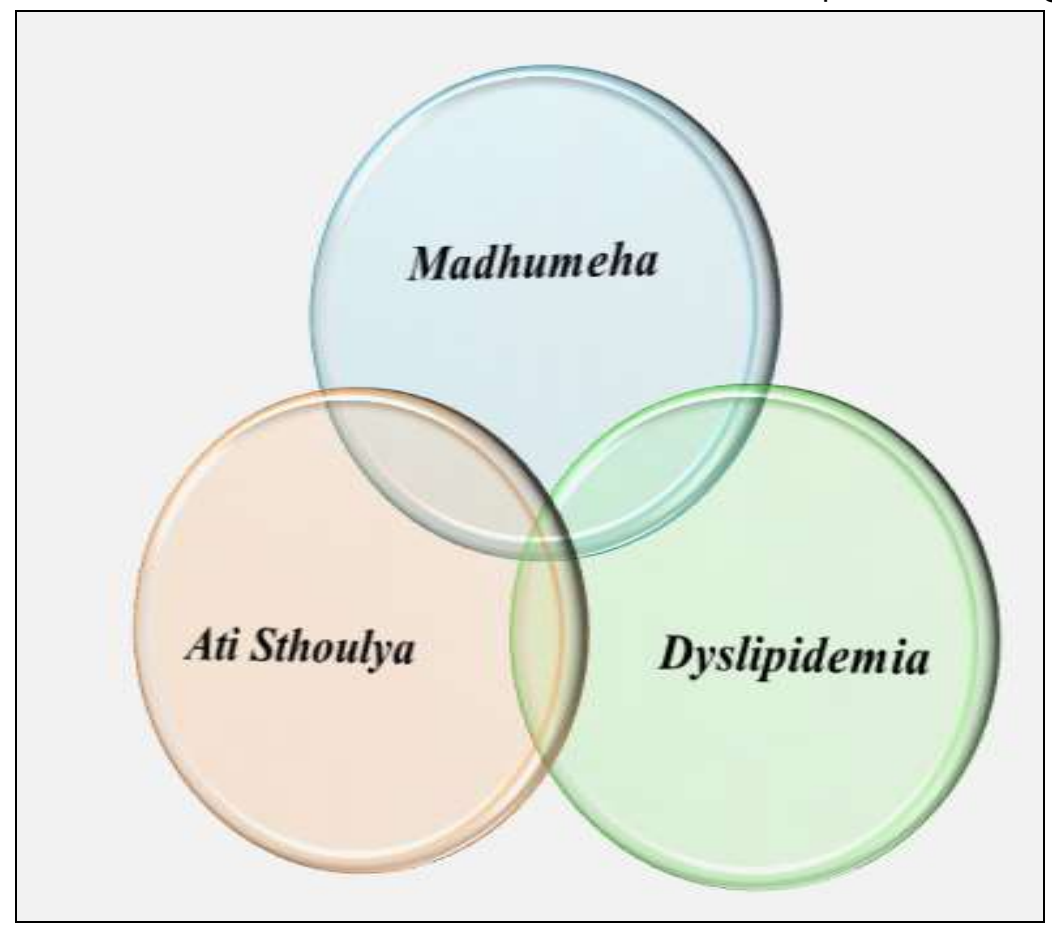

Figure 1: Common Metabolic Disorders.

\section{Dosha \& Metabolic Disorders}

Excessive intake of meat of marshy and aquatic animals, Tila oil, Payasa, Krisara, Vilepi, immature curd and dairy products, avoidance of physical exercise and excessive sleep, etc. can vitiate Kapha leading to the accumulation of Amadosa which can results dyslipidemia and obesity.

Similarly the etiological factors which can vitiates Pitta are; excess intake of food even before the digestion of the previously ingested meal, exposure to hot climatic condition, physical exertion, intake of contradictory foods, food cooked improperly and sedentary life style. The vitiation of Pitta due to the above mentioned factors can lead Medovridhi, hyperthyroidism or hypothyroidism and other metabolic abnormalities.

\section{Srotasa \& Metabolic Disorders:}

As mentioned above there are many factors which can vitiates Srotasa such as; Rasavaha, Raktavaha, Mamsavaha and Medovaha. The disturbance in these Srotasa can contributes towards the pathological progression of metabolic disorders. Various etiological factors such as Kulaja (genetic predisposition), Sahaja (etiological factors 
related to the diet, lifestyle and emotional state), Abhigata (trauma) and Purva vyadhi, etc. can vitiate functioning of Srotasas.

\section{Agni \& Metabolic Disorders:}

Etiological factors such as; Atyambupana, Vishmashana,

Sandharana,

Swapnaviparyaya, Bhaya, Krodha, Chinta, Shoka, Dukh and Rug dainya, etc. can causes Mandata in Dhatvagni leading to the abnormality in adipose tissue, irregular hormonal control and production of Ama. These all consequences can lead pathogenesis of metabolic disorders.

\section{Dhatus \& Metabolic Disorders:}

Malnutrition, fasting, presence of chronic diseases, excessive exercise, drug abuse, smoking, drinking habits, improper dietary routine and lack of nutritional diets, etc. can cause vitiation of Dhatus such as; Mamsa, Meda and Rakta Dhatu which ultimately initiates pathogenesis of metabolic disorders.

Role of etiological factors towards the specific symptoms of metabolic disorders:

Etiological factors such as; Avyayama, Divasvapna and Medyanam Ati Bhakshanat, etc. can imparts symptoms of early diabetes, thirst, laziness and weakness.

Excessive consumption of Guru, Lavana \& Amla Rasa, improper sleep and emotional factors can cause fatigue, Ojas Kshaya, irregular dietary urges and infrequent urination as symptoms of metabolic disorders.

Genetic factors, environmental factors and disturbed daily regimen, etc. can leads symptoms of hormonal imbalance, anorexia, thirst and cardiac problems associated with obesity and diabetes.

\section{Role of Etiological Factors in Atisthaulya:}

Etiological factors such as; Adhyashana, Atisampurna, Guru Ahara Sevana, Madhura Ahara sevana, Shleshmala Ahara Sevana, Avyayama, Diwaswapa, consumption of high fat diet, genetics factors, endocrine disorders and psychiatric illness, etc. can causes obesity. The aggravation of these factors vitiates Kapha which down regulates Jatharagni and suppress Meda-Dhatvagni, moreover production of Ama which vitiates MedaDhatu which obstruct Srotas leading to the Vata-Dosha dysfunction. This vitiated VataDosha increases hunger and vitiates Dhatus, these all consequences together leads Sthaulya.

\section{Role of Etiological Factors in Prameha:}

Etiological factors such as; Atisampooranat, Guru madhura sheetasnigdhopayogat, Avyayamat, Avyvayat, Divaswapnat, Beejaswabhavat, Chinta and Madyapana, etc. can cause diabetes and it is also associated with obesity. Indulgence in above mentioned Nidana can cause Aparipakwa Kapha and Meda along with vitiation of Kleda, further aggravation of vitiated Rasa Dhatu with imbalances of Tridoshas mainly Kapha leads disease manifestation.

\section{Conclusion}

The metabolic disorders in current scenario being considered as major health issue due to their high number of incidences. Vitiation of Agni, production of Ama, disturbed functioning of Dhatus, aggravation of Dosha and obstruction of Srotasa mainly involved in pathological events of metabolic disorders like; Ati 2020 November Edition | www.jbino.com | Innovative Association 
Sthoulya, Srotsam Lepa, Madhumeha and dyslipidemia, etc. Ayurveda described Atyambupana,

Vishmashana, Swapnaviparyaya, Krodha, Chinta, Shoka, Rug dainya, Avyayama, Divasvapna, Medyanam Ati Bhakshanat, Guru Ahara Sevana, Madhura Ahara sevana, Shleshmala Ahara Sevana, Beejaswabhavat and Madyapana, etc. as major etiological factors involved in the pathological events of metabolic disorders. These factors not only initiates disease pathogenesis but also fasten pathological progression if aggravated inside the body for long time, therefore avoidance of causative factors is prime approach to prevent prevalence of such diseases.

\section{References}

1. Gaddam K.K, Ventura H.O, Lavie C.J "Metabolic syndrome and heart failure" the risk, paradox, and treatment. Current Hypertension Rep. 2011:13:142-8.

2. Chakradutta. Chakrapanidutta, Vaidyprabha Hindi Commentary by Tripathi, Indradev Chaukhabha Sanskrit Sansthan Varanasi. 1997.

3. Kaur J (2014). "A comprehensive review on metabolic syndrome". Cardiology Research and Practice, 2014:

943162.

doi:10.1155/2014/943162.PMC 396 6331. PMID 24711954.

4. Agnivesh, Charaka, Dridhbala, Charaka Samhita, Chikitsasthan, 28/238-240. English Translation by
Sharma RK and Bhagwan Dash. Vol. 4. Reprint. Chowkhamba Sanskrit Series Office, Varanasi, 2009.

5. Charaka samhita, Sootra sthana, Chaukhamba publication, Reprint edition - 2011 23rd chapter, verse 0307, pg no - 122, pp - 738 .

6. Shushruta samhita, Sootra sthana, Chaukhamba publication, Reprint edition - 2011 15th chapter, verse 32, pg no - 73pp-824.

7. Acharya YT (2009). Sushrutha Samhita with Nibandhasangraha commentary of Dalhana: Chowkambha Orientalia, Varanasi, Reprint ed. 2,106,148, 255.

8. Astanga Hridayam, Vagbhata, Vidyodini hindi commentary with Commentary by Kaviraj Atrideva Gupta, Editor Vaidya Yadunandan Upadhyay, Chowkhambha Prakashan, Varanasi, 2007.

9. Bhavprakash, Bhavprakash Nighantu Indian Meteria MedicaOf Shri Bhavamishra, commentary by Dr K. C. C hunekar, edited by Dr. G.S. Pandey, Chowkhambha bharti academy Varanasi, Reprint 2009.

10. Sharma PV: Chaukhambha Bharti Academy, Varanasi, Dravya Guna Vijnana. Vol. II, reprint (2003).

11. Agnivesha, Charaka, Dridhabala, Charaka Samhita with Ayurveda Dipika commentary,edited by Vaidya Jadavaji Trikamji Aacharya, Chaukhamba Prakashan, Varanasi, 2007. 